\title{
sciendo
}

CIVIL AND ENVIRONMENTAL ENGINEERING REPORTS

E-ISSN 2450-8594

CEER 2019; 29 (2): 013-021

DOI: $10.2478 /$ ceer-2019-0012

Original Research Article

\section{CHARACTERISTICS OF WATER CONSUMPTION IN CHO-CIANÓW, PARCHÓW AND POGORZELISKA, LOWER SILESIA PROVINCE}

\author{
Ewa OGIOŁDA ${ }^{1}$, Ireneusz NOWOGOŃSKI, Przemysław PIETRZAK \\ University of Zielona Gora, Zielona Góra, Poland
}

\begin{abstract}
Water consumption is an amount characteristic to individual water sup-ply systems. It is described by values of the unitary consumption of water and unevenness coefficients. An analysis of consumption for the years 2009-2016 in two systems which are diverse in terms of the number of supplied recipients as well as the intended water use is presented. The values of unitary consumption indices as well as hourly and daily irregularity of consumption were calculated, and factors influencing the irregularity of consumption in different time frames indicated. Conclusions regarding the amount and irregularity of consumption were drawn and compared with guidelines and other analysed systems.
\end{abstract}

Keywords: water supply system, water consumption, irregularity of water consumption

\section{INTRODUCTION}

The basis for dimensioning water supply systems is a balance sheet, created based on the "Guidelines for Programming the Water Demand and the Amount of Waste Water in Urban Settlement Units" [6]. Values established in such a way are verified on operating systems. For many years now, restricted water consumption has been observed in Poland $[1,2,3,6,7,8,12]$, with changes in the way of

\footnotetext{
${ }^{1}$ Corresponding author: University of Zielona Gora, Architecture and Environmental Engineering, Institute of Environmental Engineering, Z. Szafrana 15, 65-001 Zielona Góra, e-mail: e.ogiolda@iis.uz.zgora.pl, tel. 48683282683
} 
calculating water consumption, the installation of water metres, or the rising price of water indicated among the factors causing such a state of things $[4,9,12,14]$. An important aspect is also the irregularity of water consumption, which may be analysed in various time frames - year, month, week or day. Factors determining such variation include lifestyle, habits, or the organization of the water recipients' workday, as well as meteorological conditions $[12,14]$.

Water consumption and its irregularity are reflected in the reliability of both the water distribution as well as waste water disposal system. These values influence the retention period and, as a consequence, the quality of the water that the recipients are supplied with $[5,11]$.

Information collected in the period of eight years was the basis for calculating the values characterizing water consumption in two water supply networks in Lower Silesia Province. Subjected to analysis was the measure and irregularity of water consumption in various time frames.

\section{CHARACTERISTICS OF WATER SUPPLY SYSTEMS}

The analysis concerns water usage in two water supply systems. One of them provides water to the city of Chocianów, and the other to the villages of Parchów and Pogorzeliska, located in Chocianów County of Polkowicki District in Lower Silesia Province (Figure 1).

The analysed systems are supplied by underground water intakes. They vary significantly in terms of size; the water supply system in Chocianów is approximately $45 \mathrm{~km}$, in Parchów approx. $17 \mathrm{~km}$, and in Pogorzeliska - approx. $9 \mathrm{~km}$. The number of inhabitants supplied with water in the individual settlement units in the years 2009-2016 has been presented in Table 1.

Tab. 1. Number of inhabitants in the analysed settlement units in the years 2009-2016

\begin{tabular}{|c|c|c|c|}
\hline \multirow{2}{*}{ Year } & \multicolumn{3}{|c|}{ Population } \\
\cline { 2 - 4 } & Chocianów & Parchów & Pogorzeliska \\
\hline 2009 & 8155 & 565 & 204 \\
\hline 2010 & 8310 & 585 & 208 \\
\hline 2011 & 8297 & 597 & 215 \\
\hline 2012 & 8274 & 614 & 219 \\
\hline 2013 & 8194 & 620 & 220 \\
\hline 2014 & 8122 & 631 & 230 \\
\hline 2015 & 8073 & 643 & 226 \\
\hline 2016 & 8074 & 652 & 230 \\
\hline
\end{tabular}




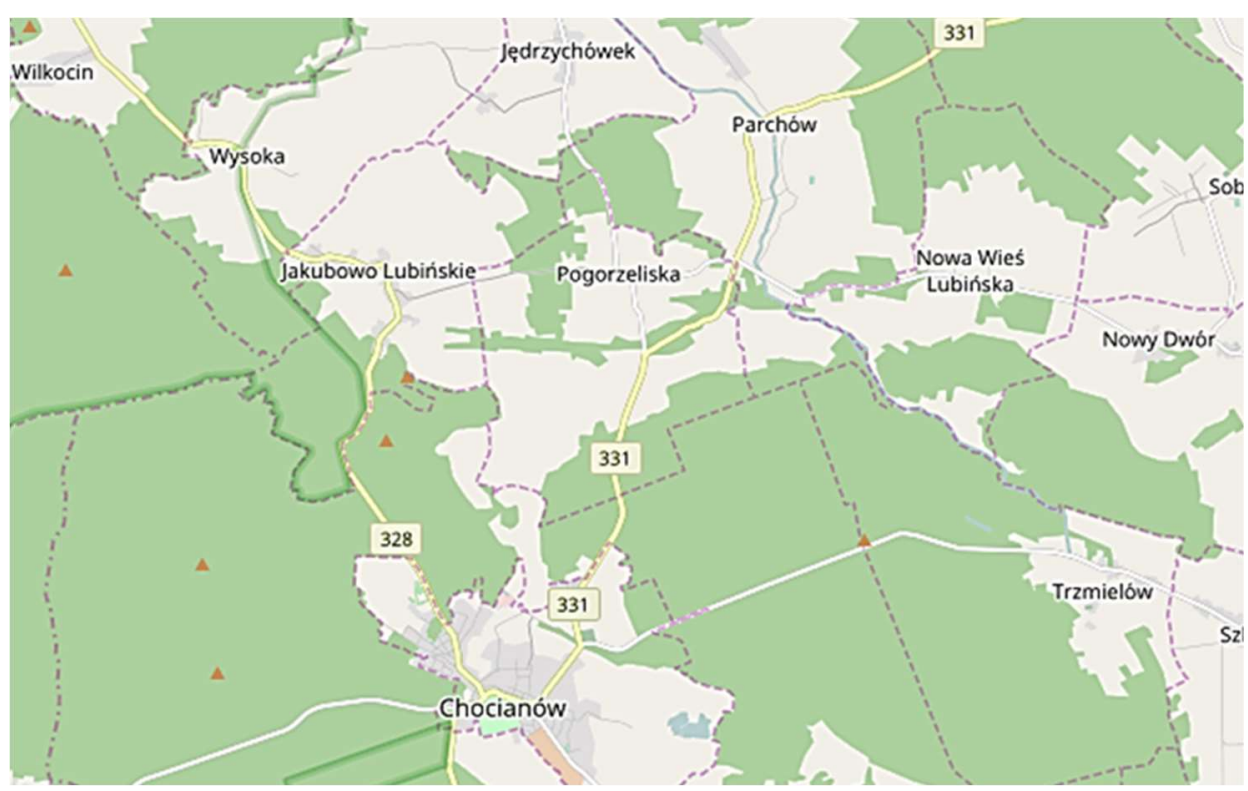

Fig. 1. Location of the analysed water supply systems

The number of inhabitants in the city of Chocianów reveals a decreasing tendency, with an increase in population noted in the villages of Parchów and Pogorzeliska.

Tab. 2. Annual water consumption in the analysed water supply systems in the years 2009-2016

\begin{tabular}{|c|c|c|}
\hline \multirow{2}{*}{ Year } & $\begin{array}{c}\text { Water supply network of the city } \\
\text { of Chocianów }\end{array}$ & $\begin{array}{c}\text { Water supply system of the } \\
\text { villages of Parchów and } \\
\text { Pogorzeliska }\end{array}$ \\
\cline { 2 - 3 } & \multicolumn{2}{|c|}{ Annual water consumption $\left[\mathrm{m}^{3}\right]$} \\
\hline 2009 & 446744 & 30985 \\
\hline 2010 & 433806 & 29749 \\
\hline 2011 & 437258 & 33508 \\
\hline 2012 & 436684 & 27665 \\
\hline 2013 & 457740 & 28588 \\
\hline 2014 & 451819 & 31802 \\
\hline 2015 & 418407 & 32465 \\
\hline 2016 & 383002 & 32457 \\
\hline
\end{tabular}

The intended use of the water also varies. In Chocianów, it is used mainly for residential needs, whilst in Parchów and Pogorzeliska, water is intended for the needs of inhabitants and farmsteads. The annual water consumption in the individual water supply systems has been presented in Table 2 . 


\section{RESEARCH RESULTS}

The analysis was prepared using data on water consumption in Chocianów, Parchów and Pogorzeliska in the years 2009 - 2016. Parameters characterizing the measure and irregularity of water consumption were calculated.

The following formulas were used to perform the calculations:

- unitary indicator of water consumption $\mathrm{q}_{\mathrm{j}}$ :

$$
\mathrm{q}_{\mathrm{j}}=\frac{\mathrm{Q}_{\mathrm{dav}}}{\mathrm{M}}
$$

where:

$\mathrm{M}$ - number of inhabitants,

- daily irregularity coefficient $\mathrm{N}_{\mathrm{d}}$ :

$$
\mathrm{N}_{\mathrm{d}}=\frac{\mathrm{Q}_{\mathrm{d} \max }}{\mathrm{Q}_{\mathrm{dav}}}
$$

where:

$\mathrm{Q}_{\mathrm{d} \text { av }}$ - average daily water consumption, $\mathrm{m}^{3} \cdot \mathrm{d}^{-1}$,

$\mathrm{Q}_{\mathrm{d} \max }-$ maximum daily water consumption, $\mathrm{m}^{3} \cdot \mathrm{d}^{-1}$,

- hourly irregularity coefficient $\mathrm{N}_{\mathrm{h}}$ :

$$
\mathrm{N}_{\mathrm{h}}=\frac{\mathrm{Q}_{\mathrm{hmax}}}{\mathrm{Q}_{\text {hav }}}
$$

where:

$\mathrm{Q}_{\mathrm{h} \text { av }}$ - average hourly water consumption, $\mathrm{m}^{3} \cdot \mathrm{h}^{-1}$,

$\mathrm{Q}_{\mathrm{h} \max }-$ maximum hourly water consumption, $\mathrm{m}^{3} \cdot \mathrm{h}^{-1}$.

Based on data regarding daily water consumption and the number of inhabitants, the values of unit water consumption indicators were calculated from Formula (3.1). The results have been presented in Figure 2.

In the analysed time period, the average unitary consumption of water amounted to $144.9 \mathrm{~m}^{3} \cdot \mathrm{M}^{-1} \cdot \mathrm{d}^{-1}$, decreasing by over $13 \%$, whilst in Parchów and Pogorzeliska, it amounted to $101.9 \mathrm{~m}^{3} \cdot \mathrm{M}^{-1} \cdot \mathrm{d}^{-1}$, decreasing by $8.5 \%$. The next step of the analysis was determining the coefficients of hourly and daily irregularity of water consumption. For this purpose Formulas (3.2) and (3.3) were used, and the results of the calculations have been compiled in Table 3 . 


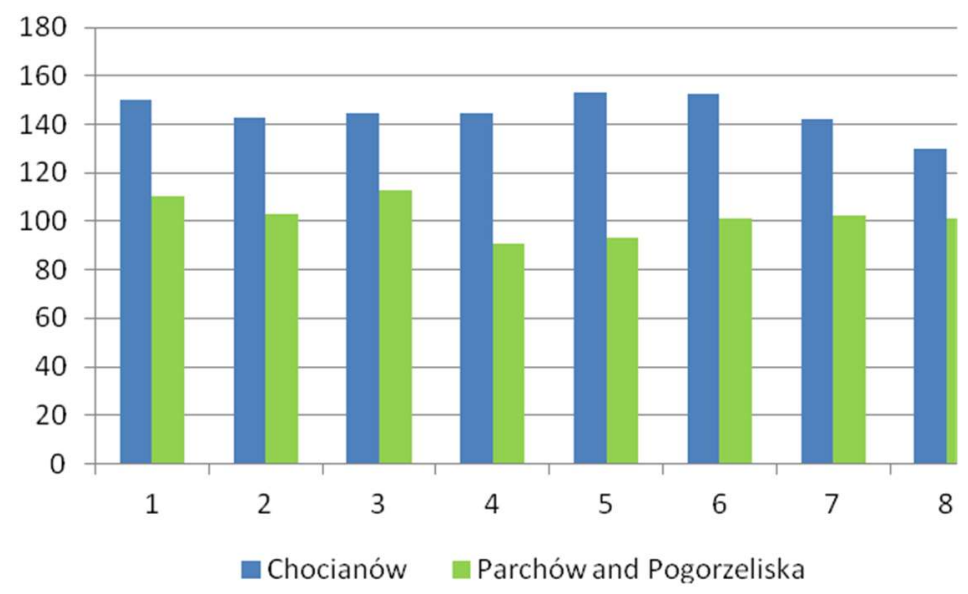

Fig. 2. Variability of unitary water consumption in the years 2009-2016

Tab. 3. Coefficients of water consumption irregularity in individual water supply systems

\begin{tabular}{|l|c|c|}
\hline \multicolumn{1}{|c|}{ Water supply system } & $\mathrm{N}_{\mathrm{d}}$ & $\mathrm{N}_{\mathrm{h}}$ \\
\hline Chocianów & 1.28 & 2.07 \\
\hline Parchów and Pogorzeliska & 1.40 & 1.77 \\
\hline
\end{tabular}

The obtained values of water consumption irregularity coefficients do not deviate from the "Guidelines for Programming Water Demand and the Amount of Waste Water in Urban Settlement Units" [5].

The variability of water consumption in various time frames during the years 2014 - 2016 was also subject to analysis. Water consumption in the individual months of the year has been shown in Figures 3 and 4.

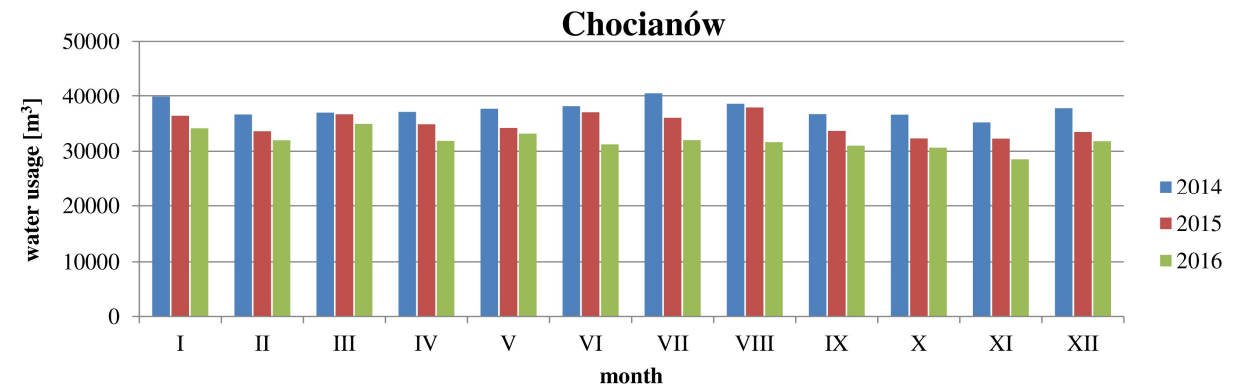

Fig. 3. Average monthly water consumption in Chocianów in the years 2014-2016 


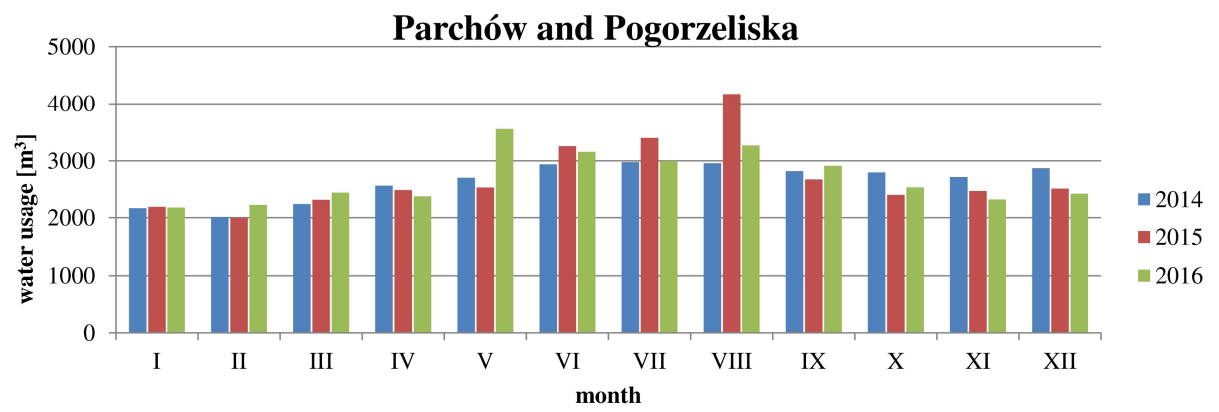

Fig. 4. Average monthly water consumption in Parchów and Pogorzeliska in the years $2014-2016$

Variability in water consumption in the individual months of the year confirms the diverse nature of the individual systems and supplied recipients, as well as the influence of meteorological conditions.

Further detailed analyses regarding the variability in water consumption in individual days of the week and at different times of day were carried out based on readings of water consumption carried out every hour, from 01.01 to 31.12.2016, for the water supply system supplying the city of Chocianów. The results of the analysis of water consumption in individual days of the week have been presented in Figure 5.

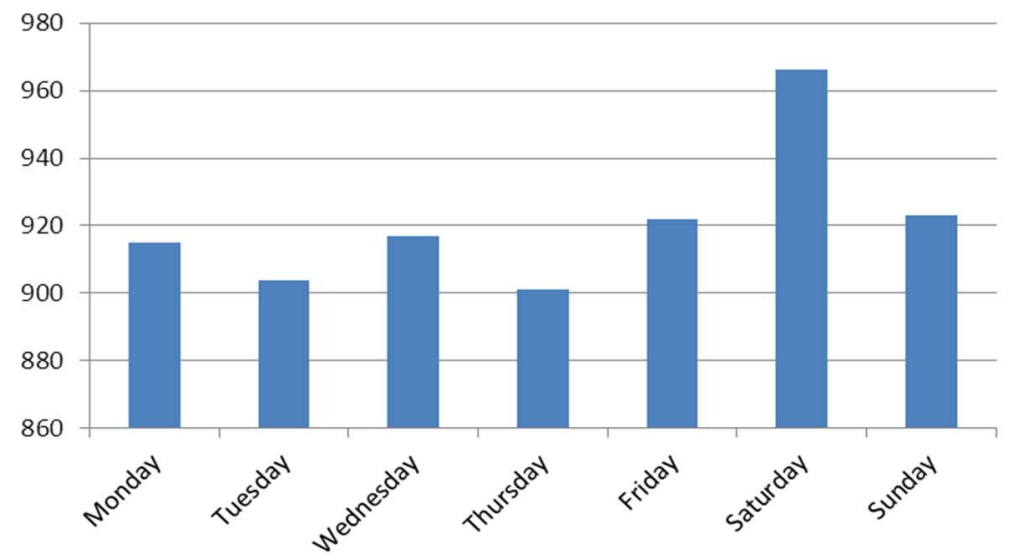

Fig. 5. Water consumption on individual days of the week in the water supply system of the city of Chocianów

In Chocianów, significant variation in water consumption between the individual days of the week is not noticeable. The highest water consumption can be observed on Saturdays, with the lowest on Thursdays. This is connected with the 
lifestyle of the inhabitants - spending time outside of the house during the week and doing housework at the weekend.

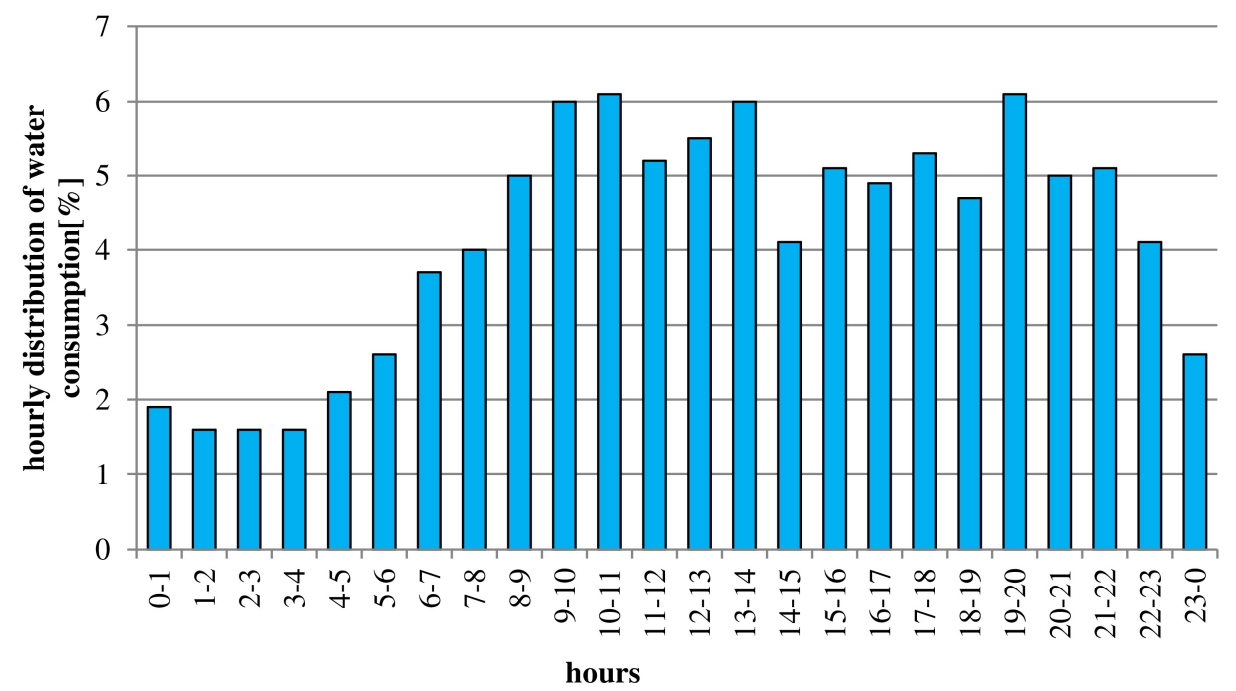

Fig. 6. Hourly distribution of water consumption in the water supply system of the city of Chocianów

An analysis of water consumption over the course of a day with maximum water consumption was also carried out. For this purpose, a graph presenting the percentage distribution of water consumption over the course of a day characterized by maximum water consumption was prepared (Figure 6).

Three peaks are visible in the course of the hourly distribution of water consumption: morning, afternoon and evening. The most water is consumed in the following hours: 10-11, 13-14 and 19-20, whilst the lowest between 1 and 4 . Such a state of matters may be connected with the lifestyle of city inhabitants - a large group of people is employed in the service industry, which is characterized by different working hours than those of manufacturing plants.

\section{CONCLUSIONS}

The article presents an analysis of results gathered during an eight-year operational period (2009-2016) of two water supply systems in Lower Silesia Province. One supplies water to the city of Chocianów, and the other - the villages of Parchów and Pogorzeliska. The average unitary water consumption for the analysed period amounted to $144.9 \mathrm{~m}^{3} \cdot \mathrm{M}^{-1} \cdot \mathrm{d}^{-1}$ for Chocianów and $101.9 \mathrm{~m}^{3} \mathrm{M}^{1} \cdot \mathrm{d}^{1}$ for Parchów and Pogorzeliska, in both cases revealing decreasing tendencies. The 
calculated values are significantly higher than those observed by Bugajski and Kaczor [3] in the area of Drwinia County, and by Kuczyński and Żuchowicki [15] in the water supply systems in the area of cities and villages of Lower Silesia Province. The obtained results also differ from those presented by Ogiołda and Kozaczek [10] as well as Ogiołda et al [11]. The results obtained for the water supply system supplying the villages of Parchów and Pogorzeliska do not differ significantly from those reported by Bergel [2], while results obtained for the water supply system of the city of Chocianów are similar to those noted by Ogiołda et al. [10].

The calculated values of irregularity coefficients coincide with those given in the "Guidelines for Programming Water Demand and the Amount of Waste Water in Urban Settlement Units" [5].

The results of the analysis confirmed that variability in water consumption is dependent on various factors. Seasonal changes are connected with meteorological factors, and in rural areas, also with works carried out around farms. The variability in water consumption over the course of a week or day confirms the influence of factors such as the lifestyle of the inhabitants and carrying out responsibilities connected with running a household.

The presented analysis may prove useful in taking decisions regarding the operation of water supply systems and lead to the rationalization of investment and operational costs.

\section{REFERENCES}

1. Bajer, J and Iwanejko, R 2014. Dynamics of Changes in the Unitary Consumption of Water in Selected Cities of Southern Poland (Dynamika zmian jednostkowego zużycia wody w wybranych miastach Polski południowej). Instal - teoria i praktyka w instalacjach 4, 64-68.

2. Bergel, T 2013. Water Consumption in Rural and Urban-Rural Water Supply Systems in Poland (Zużycie wody w wiejskich i miejsko-wiejskich wodociągach w Polsce). Gaz, Woda i Technika Sanitarna 2, 99-101.

3. Bugajski, P and Kaczor, G 2007. Structure of Water Consumption by Users of the Water Supply System in Drwinia County (Struktura zużycia wody przez użytkowników wodociągu w gminie Drwinia). Infrastruktura $i$ Ekologia Terenów Wiejskich 2, 81-88.

4. Effects of Water Age on Distribution System Water Quality 2002. U. S. Environmental Protection Agency.

5. Guidelines for Programming the Water Demand and the Amount of Waste Water in Urban Settlement Units (Wytyczne do programowania zapotrzebowania wody i ilości ścieków w miejskich jednostkach osadniczych). 1991. Warszawa: Instytut Gospodarki Przestrzennej i Komunalnej. 
6. Heidrich, Z and Jędrzejkiewicz, J 2007. Analysis of Water Consumption in Polish Cities in the Years 1995-2005 (Analiza zużycia wody w miastach polskich w latach 1995-2005). Ochrona Środowiska 4, 29-34.

7. Kłoss-Trębaczkiewicz, H and Osuch-Pajdzińska, E 2006. Analysis of Tendencies of Changes in Water Consumption in Polish Cities (Analiza tendencji zmian zużycia wodyw miastach polskich). Ochrona Środowiska 4, 63-67.

8. Mikołajczyk, M 2012. Analysis of Unitary Water Consumption Indices in Households under Urban and Rural Conditions (Analiza jednostkowych wskaźników zużycia wody w gospodarstwach domowych w warunkach miejskich i wiejskich). Instal - teoria i praktyka w instalacjach 2, 47-49.

9. Nowogoński, I and Ogiołda, E 2017. Modelling Parameters Characterizing selected Water Supply Systems in Lower Silesia Province (Modelowanie parametrów wybranych systemów zaopatrzenia w wodę w województwie dolnośląskim). Civil and Environmental Engineering Reports 27(4), 67-75.

10.Ogiołda, E and Kozaczek, M 2013. Characteristics of Water Consumption in Water Supply Systems in "Wilków" and "Borek" in Głogów Commune (Charakterystyka zużycia wody w systemach wodociągowych "Wilków” i , Borek” w gminie Głogów). Zeszyty Naukowe Uniwersytetu Zielonogórskiego. Seria: Inżynieria Środowiska 32, 69-77.

11. Ordinance of the Minister of Infrastructure of 14.01.2002 on Determining the Average Water Consumption Standards (Rozporzadzenie Ministra Infrastruktury $z$ dn. 14.01.2002r. $w$ sprawie określenia przeciętnych norm zużcia wody) Dz. U. z dn. 31.01.2002r.

12. Pasela, R and Gorączko, M 2013. Analysis of Selected Factors Determining Water Consumption in Multi-Family Buildings (Analiza wybranych czynników kształtujących zużycie wody w budynkach wielorodzinnych). Rocznik Ochrona Środowiska 15, 1658-1672.

13. Pasela, R and Klugiewicz, J 2006. Structure of Water Consumption in the Biggest Cities of Kujawsko-Pomorskie Province (Struktura zużycia wody w największych Miastach woj. kujawsko - pomorskiego). Instal 1, 49-52.

14. Żuchowicki, A and Kuczyński, W 2009. Comparative Analysis of Changes in Water Demands Accounting for the Means of Supplying it to Consumers (Analiza porównawcza zmian w rozbiorach wody z uwzględnieniem sposobu jej dostarczania do odbiorców). Środkowo - Pomorskie Towarzystwo Naukowe Ochrony Środowiska 11, 781 - 786.

Editor received the manuscript: 04.02.2019 